地 震第 2 輯

第 44 巻特集号 (1991) 289-299 頁

\title{
岩石破壊と地震
}

\author{
名古屋大学理学部地球科学教室* 増 田 幸 治**
}

\section{A Review of the Study of Rock Mechanics}

\begin{abstract}
Koji Masuda
Department of Earth Sciences, Nagoya University, Furo-cho, Chikusa-ku, Nagoya, Aichi, 464-01 Japan

(Received November 3, 1989; Accepted November 16, 1990)

Rock mechanics experiments in a laboratory have provided useful information on the physical process of earthquakes. Our knowledge of rock fracture has increased rapidly because of recent developments in experimental equipment and techniques. Acoustic emission activity, spatial variation of $\mathrm{AE}$ hypocenter distribution, and focal mechanism solution of $\mathrm{AE}$ have the same properties as natural earthquakes. These suggest the processes earthquakes and microfracturing are related. However, the large time-scale and space gaps between laboratory experiments and real earth phenomena must be bridged in order to apply the results of laboratory experiments to natural earthquakes. Time-dependent fracture properties of rocks and frictional behavior have been described by a strain-rate or slip-rate dependent law. Size-scale dependence of physical parameters is controlled by the inhomogeneous structure of rocks and/or surface roughness of fault.
\end{abstract}

Key words: Rock mechanics, Acoustic emission, Fracture, Earthquakes.

\section{§1.はじめに}

地震は地殼やマントル上部でおこる岩石の急激な破壊 あるいはすべり現象である. 岩石破壊実験は実験室内で 地震現象を再現する地震シミュレーションといえる．と くに自然地震では正確な測定が困難と思われる震源域の 応力や変形の精密な測定などが実験室内では可能であ る.しかあコントロールされた環境や条件のもとで破壊 現象やすべり現象をくりかえし連続的に観測できるの で, 地震発生のメカニズムや地震の前兆現象解明の有力 な手段といえる.1960 年ごろからこのような立場に たった岩石破壊実験の研究が日本, アメリカ, ソ連など で開始され，今日では各国で活発な研究が進められてい る [例えば Mogi (1962a, 1967), BRACE and ByeRLEE (1966)].

しかしながら, 実験室内における微小破壊やすべりと 地震のような自然現象とは, 時間的・空間的スケールに 大きな差がある. 室内実験の結果を自然地震に適用する まえに，これらの違いが破壊現象に与える影響を明らか

* $\mathbf{T} 464-01$ 名古屋市千種区不老町

** 現所属 地質調查所 $\mathbf{T} 305$ 茨城県つくば市東 1$1-3$
にするスケーリング則を確立しなければならない． 1980 年代の岩石破壊実験は，このようなスケーリング 則や破壊の素過程の物理法則を得ようとする方向にあ る。これは岩石破壊実験の結果を単純に地震現象と比較 するという従前の傾向と比べると大きな質的変化という ことができる. その意味で実験室スケールの岩石破壊研 究は地震現象の物理的本質に迫ってきたといえる.

岩石破壊研究の総合解説には今まで数多くのものがあ る. たとえば 1970 年代前半までのものについては MOGI (1973), 1970 年代後半までの屯のについては PATERSON (1978) がある. 地震との関連でまとめたもの としては茂木 (1978)，大中 (1987) があり文献などに詳 しい. 岩石の脆性破壊や摩擦の基本的概念之, 地震・断 層運動のメカニズムについて, 最近 SCHOLZ (1990) の text がでた. 本論では岩石破壊現象と地震との関連に焦 点をあて，それらの類似性をのべ，モデル実験と自然現 象の間のスケーリングについてまとめる.

\section{$\S 2$. 地震と岩石破壊現象の類似性}

岩石破壊実験における最近の計測手法の進歩には目を 見張るものがある. 現在岩石実験では, 応力, 歪, アコー 


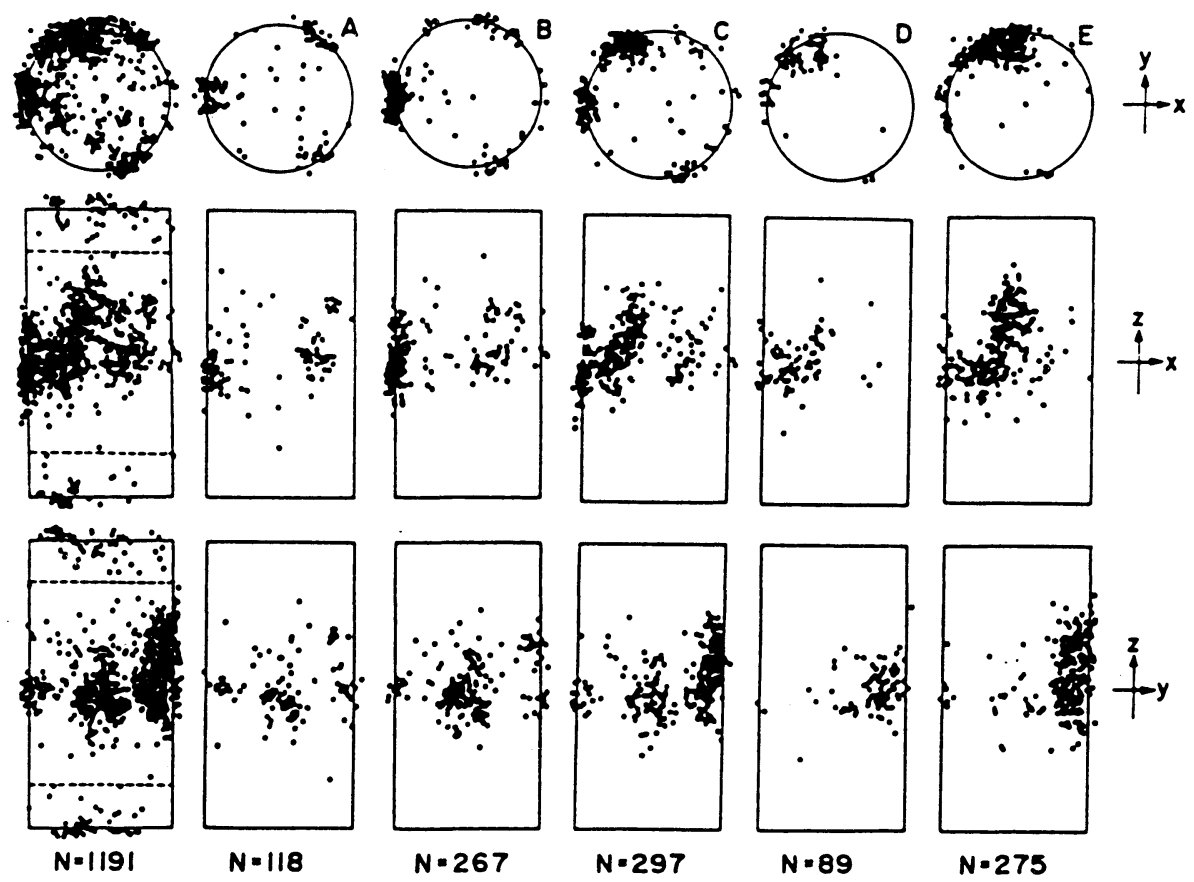

Fig. 1. Spatial variation of AE hypocenter distribution [NISHIzAwA et al. (1985)]. All events located throughout the experiment are plotted (left). The experiment was divided into 5 periods: A, primarycreep, B, steady-creep, C, acceleration-creep of phase I, D, phase II, E, phase III. AE hypocenters tended to form clusters during steady-creep. During acceleration-creep, the preceding clusters disappeared while a new cluster appeared in an incipient fault. Hypocenters near both ends are omitted.

スティック・エミッション（微小破壊音, $\mathrm{AE})$, 弾性波 速度, 電磁波, 光などの項目が測定されている. 歪の測 定については，DIETRICH (1981) の半導体歪ゲージを 使って高速の歪変化をとらえる方法や, SPETZLER et al. (1977) のホログラフィー干渉法による測定法が開発さ れた. AEの測定については，単に発生数を数えるのみ でなく, 多数のセンサーを使うことにより震源位置やメ カニズムの決定が可能になった [たとえば楠瀬・他 (1981)，佐藤・他 (1987)]。これら計測技術やプレス装 置の精密制御法などの進歩により, 破壊現象やすべり現 象を精密に測定できるようになり, 物理的な議論が可能 になった.この節では, 岩石試料内の微小破壊である $\mathrm{AE}$ と地震活動の類似性についてまとめる.

岩石試料中で発生する AE の振幅別発生頻度分布につ いて, MoGI (1962a) は地震と同じような GutenbergRichter の式で表される関係が成り立つことを示した. $\mathrm{b}$ 值は構造的不均一之共に増大し [MoGI (1962b)], 応力 レベルの上昇と共に減少すること [SCHOLZ (1968a)] が 観測された. 平田・他 (1985) は定荷重クリープ破壊実 験をおこない, b 值が 2 次クリープから 3 次クリープの 期間にかけて徐々に小さくなり, 主破壊直前では急激な
低下がみられることを明らかにした。 また，最近 MAIN et al. (1989) は地震の前に b 值が時間的に変化を示すこ とを破壊力学的考察加ら説明している. AE の最大振幅 の頻度分布は地震の最大振幅の頻度分布と同じ法則に 従っている.

AE 発生の時系列について, HiRATA (1987) はクリー プ実験中に観測した AE のバーストを主震とそれにつづ く余震群とみなし, 余震 $\mathrm{AE}$ の時系列について調べた. 余震 $\mathrm{AE}$ の発生率は時間の経過とともに指数関数的減衰 から，自然地震の余震系列を表す式として使われている 大森公式に従った減衰のしかたに变わっていく.

AE 震源分布の研究は Scholz (1968b) がはじめて一 軸圧縮下で 22 個の震源を決定したが，決定数が少ない ことと精度に問題があることから何らかの結論を導くこ とができなかった. MoGI (1968) は角形試料の 4 点曲げ による際に発生する $\mathrm{AE}$ 震源の 2 次元分布を求めて, 主 破壊が近づくにつれて $\mathrm{AE}$ 震源が主破壊の起こる領域に 集中することを見いだした。しかし曲げ応力は地款内に 働く応力としては考えにくく，圧縮応力下での 3 次元震 源分布の研究が必要であると考えられた。 その後 LocKNER and BYRELEE (1977) は複数のセンサーで受信され 

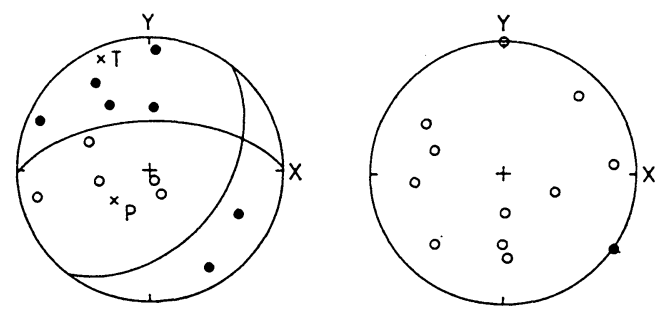

Fig. 2. Two types of focal mechanism solutions of AE [SАтон et al. (1986)]. Quadrantial distribution of P-wave first motion polarities (left), and the distribution in which almost all P-wave first motion polarities are dilatational (right). First motions are projected on a lower hemisphere equal-area projections. Open and solid circles denote dilatational and compressional, respectively.

た $\mathrm{AE}$ の振幅がしきい值をこえた時刻を自動的に测るこ とによって震源決定をおこなった。この方法では振幅の 小さな $\mathrm{AE}$ の震源を精度よく決めることができない，初 動到達時刻を正しく読み取るためには初動部分の波形を 完全に記録して読み取る必要がある. 1980 年代に入っ て高速の波形記憶装置が普及し $\mathrm{AE}$ 波形を大量に記録で きるようになった。これを用いて最近では 20 個ほどの センサーを用いて数百個から数千個の $\mathrm{AE}$ 震源を精度よ く決め，その時空分布や主破壊面との関係，さらには初 動の押し引き分布から $\mathrm{AE}$ 発生メカニズムを決める研究 がおこなわれている。

$\mathrm{AE}$ の時間空間分布を知ることにより, $\mathrm{AE}$ の震源分 布と岩石試料内の破断面との関係を調べることができ る. 西澤・他 (1981) は加圧率一定の一軸圧縮下で, NishizAw a et al. (1985) は定荷重応力状態であるクリ一 プ下で, 岩石試料内に発生する AE がクラスターを作り 破壊が近づくにつれて破断面近くに移動することを観測 した (Fig. 1). YANAGIDANi et al. (1985) はクリープ下の 花こう岩中に発生する $\mathrm{AE}$ の震源を 3933 個決定し, 破 壊が近づくにつれて $\mathrm{AE}$ 震源分布がランダムな分布から クラスターを作りしだいに集中していくようすを観測し た. また，大きい地震前にその震源付近で小さい地震の 活動が低下する第 2 種地震空白域 [MoGI (1979)] のよう に, 大きな $\mathrm{AE}$ の発生前にその周辺の $\mathrm{AE}$ が極端に減少 する AE 空白域が観測されている [KUSUNOSE and NishizAwa (1986), 楠瀬・他 (1982)].

KAGAN and KNOPOFF (1980) によれば, 自然地震の震 源分布はフラクタル構造をしている. Hirata et al. (1987) は岩石試料内に発生する AE の震源の空間分布 をフラクタルの概念を使って定量的に評価し， $\mathrm{AE}$ 震源 分布もフラクタル構造をもつことを示した。彼らはク

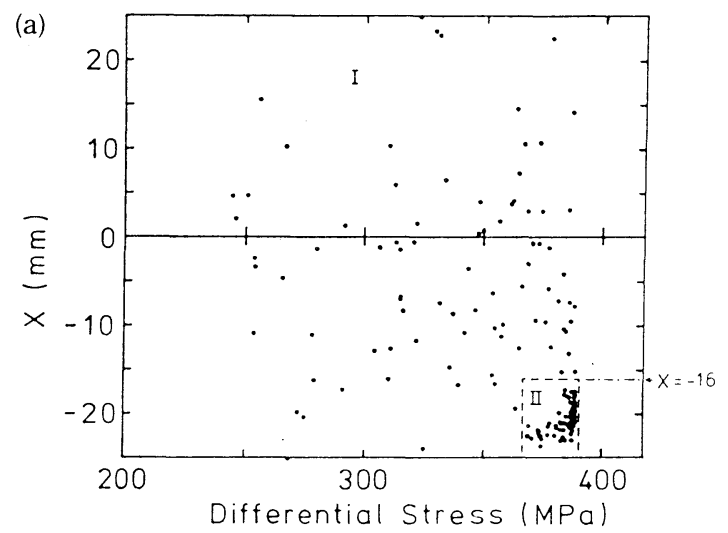

(b)

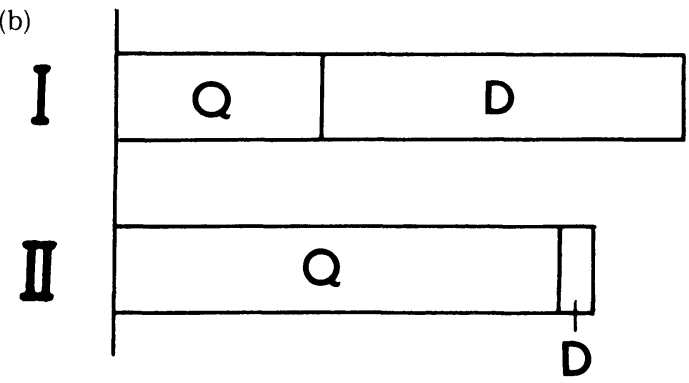

Fig. 3. (a) AE hypocenter for stress axis direction with differential stress. The events were divided into two groups, Group I : the events distributed randomly in the sample and Group II: the events belonging to the cluster enclosed by dashed square [ $\mathrm{S}_{\mathrm{ATOH}} e t$ al. (1986)]. (b) Numbers of the events classified into the type-Q and $-D$ in the group I and II. The data are from SАтон etal. (1986).

リープ下で発生する $\mathrm{AE}$ 震源の空間分布が時間とともに どう変わるかをフラクタル次元を使って調へ， 1 次ク リープ，2 次クリープ， 3 次クリープとすすむにつれて フラクタル次元が $2.75,2.66,2.55$ と小さくなっていく ことを示した。これは $\mathrm{AE}$ の震源が空間的に自己相似構 造を保ちながら集中していくことを意味している. 彼ら の結果は, 岩石の破壊現象は岩石試料中の微小破壊のよ うな微視的レベルから自然地震のような大規模なものま でスケールに依存しない自己相似過程であることを示し ている.

AE 発震機構の研究は, 楠瀬・他 (1981), SoNDERGELD and Estey (1982), Nishizawa et al. (1985) などによっ て始められた。これら初期のものはセンサーの数が少な いことから定性的な考察にとどまらざるをえない面があ る. 彼らの結果によると AEのうち多くのものは自然地 震と同じぐせん断破壊から期待される 4 象限型の初動 
押し引き分布を示す. Kusunose and NishiZAwA (1986) は $\mathrm{AE}$ の発震機構解から部分的な応力場が主震の前後で 変化することを見いだしている． $\mathrm{AE}$ の発震機構は最近 20 個程度のセンサーを用いてより詳しく研究されるよ うになった，佐藤・他 (1986) は AE を発生する微小破 壊は, せん断型の破壊から期待される 4 象限型の分布を 示すむの (type Q) だけでなく，ほとんど全点で引きが観 测されるあの (type D) があることを見いだしている (Fig. 2). 彼らは Fig. 3.に示すように一軸圧縮実験中に 発生した AE を比較的ランダムに分布している時期のむ の（グループ I ）と最終破壊直前の群発活動に属するむ の（グループII）にわけてその発震機構を議論した。震 源がランダムに分布する時期はほとんど全点で引きにな る解が約 $2 / 3$ ある。これらは圧密による孔隙の急激な閉 鎖によって AE が励起されたあのと解釈される．また群 発活動に属する AE は約 $90 \%$ が 4 象限型を示し, 発震 機構解には正断層型のものが多く, P 軸はサンプルの最 大圧縮軸方向に多く分布する. 発震機構解の研究につい てはまだデータが少なく，今後の研究課題の一つであ る.

$\mathrm{AE}$ の波形には地震の場合と同様に破壊過程に関する 情報が多く含まれているはずである。しかし， $\mathrm{AE}$ の周 波数が数百 $\mathrm{kHz}$ から数 $\mathrm{MHz}$ 程度と非常に高く, 現在 $\mathrm{AE}$ のピックアップとして広く使われている圧電素子を センサーに用いる測定系ではセンサーの周波数特性が正 確に決められないということもあって，AE の波形解析 は現在のところあまりおこなわれていない. BoLER et al. (1984) は試料表面の変位振幅の絶対値を広い周波数帯 で正確に記録できる非接触型容量センサーを開発した。 彼女らは微小破壊に伴って弾性波の形で放射されるエネ ルギーを見積っている[BOLER and SPETZLER (1986), BOLER (1990)]. Boler らのセンサーは形む大きく据置型 なので測定に際しては種種の制約もあるが，自然地震の 解析に用いられている多くの手法を応用して AE 波形解 析を行うことができれば微小破壊の物理的本質をもっと 詳しく明らかにできるはずである，AE 信号の周波数成 分に関しては, OHNAKA and MogI (1982) がバンドパス フィルターを使ってそれぞれの周波数帯で $\mathrm{AE}$ 発生数を カウントし，破壊が近づくにつれて低周波成分が卓越し てくることを報告している例がある.

\section{§3. 破壊のスケーリング則（その 1） 時間に関す るスケーリング}

先に述べたように，実験室内の岩石実験を通して自然 地震の発生過程を理解するためには，破壊過程の時間・ 空間に関するスケーリング則をあきらかにしなければな

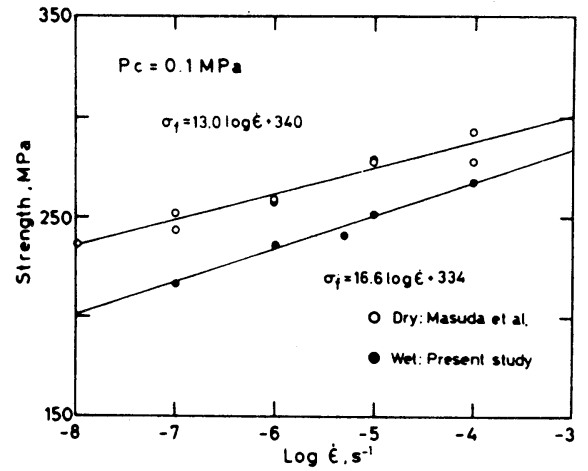

(a)

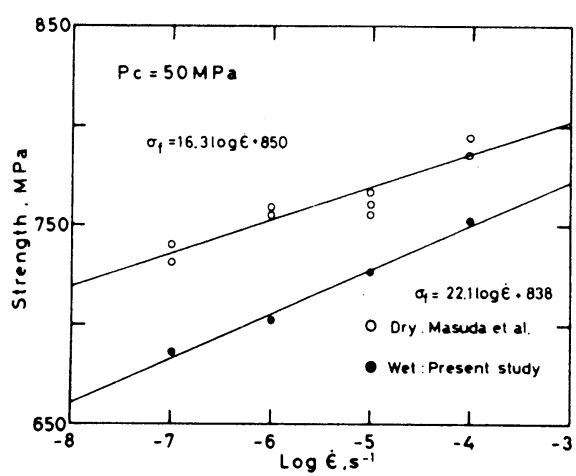

(b)

Fig. 4. Strain-rate dependence of fracture strength of dry and wet granites [MASUDA et al. (1988)]. The straight lines are computed by the least square method. Confining pressure is (a) $0.1 \mathrm{MPa}$ and (b) $50 \mathrm{MPa}$.

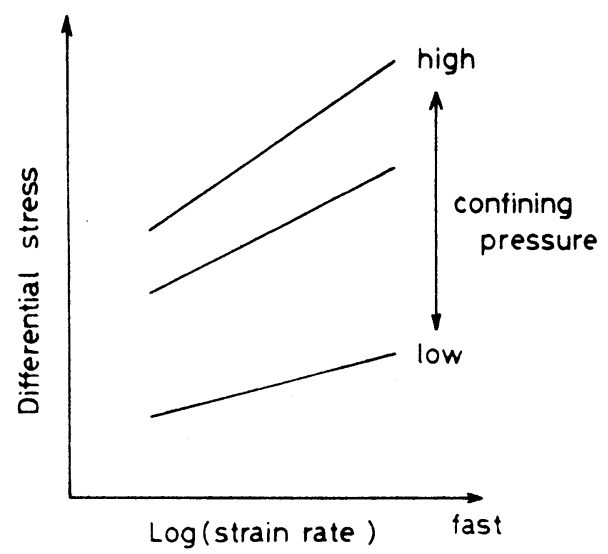

Fig. 5. Schematic diagram showing the relation between strength and strain rate at various confining pressure [MASUdA et al. (1987)].

らない，岩石破壊過程の時間（歪速度）に関するスケー リング則については, SANo et al. (1981) が大気圧下で, MASUDA et al. $(1987,1988)$ が封圧や水の効果も含めて 
組織的研究を行った．岩石破壊にともなう強度，ダイラ タンシー，地震波速度変化， $\mathrm{AE}$ 発生率などは岩石変形 の歪速度をかえると系統的に変化する，たとえば岩石の 破壊強度, $\sigma_{\mathrm{F}}$, は Fig. 4 に示すように歪速度, $\dot{\varepsilon}$ と $\sigma_{\mathrm{F}}=C \log \dot{\varepsilon}+\sigma_{0}$

という関係がある.ここで $C, \sigma_{0}$ は定数である. 係数 $C$ は破壊強度の歪速度依存性を表わす. MASUDA et al. (1987, 1988) は Fig. 5 に模式的に示すように破壊強度 の歪速度依存性は封圧の増加とともに大きくなることを 示した. 彼らが花こう岩を使って実験的に求めた (1) 式 の定数 $C$ と $\sigma_{0}$ を, 乾燥した試料の場合 $\left(C_{\mathrm{D}}, \sigma_{0 \mathrm{D}}\right)$, 水を含 んだ試料の場合 $\left(C_{\mathrm{W}}, \sigma_{0 \mathrm{~W}}\right)$ について Table 1 に示す. 水 を含んだ岩石試料の破壊強度は乾燥した岩石試料の強度
より小さくなるが，乾燥した岩石の場合と同じような式 (1) で表わされる歪速度依存性と歪速度依存性の封圧に よる増加傾向がある.

圧縮応力下で発生するダイラタンシーは, Fig. 6(a) に

Table 1. Pressure effect on the strain-rate dependence of strength [MASUda et al. (1988)].

\begin{tabular}{cccccc}
\hline \hline \multirow{2}{*}{$P_{\mathbf{c}}$} & \multicolumn{2}{c}{ Wet } & & \multicolumn{2}{c}{ Dry } \\
\cline { 2 - 3 } \cline { 5 - 6 }$(\mathrm{MPa})$ & $C_{\mathrm{W}}$ & $\sigma_{0 \mathrm{~W}}$ & & $C_{\mathrm{D}}$ & $\sigma_{0 \mathrm{D}}$ \\
\hline 0.1 & 16.6 & 334 & & 13.0 & 340 \\
50 & 22.1 & 838 & & 16.3 & 850 \\
100 & 22.4 & 1,091 & & 20.0 & 1,121 \\
200 & 27.2 & 1,449 & & 30.7 & 1,494 \\
\hline
\end{tabular}

(a)

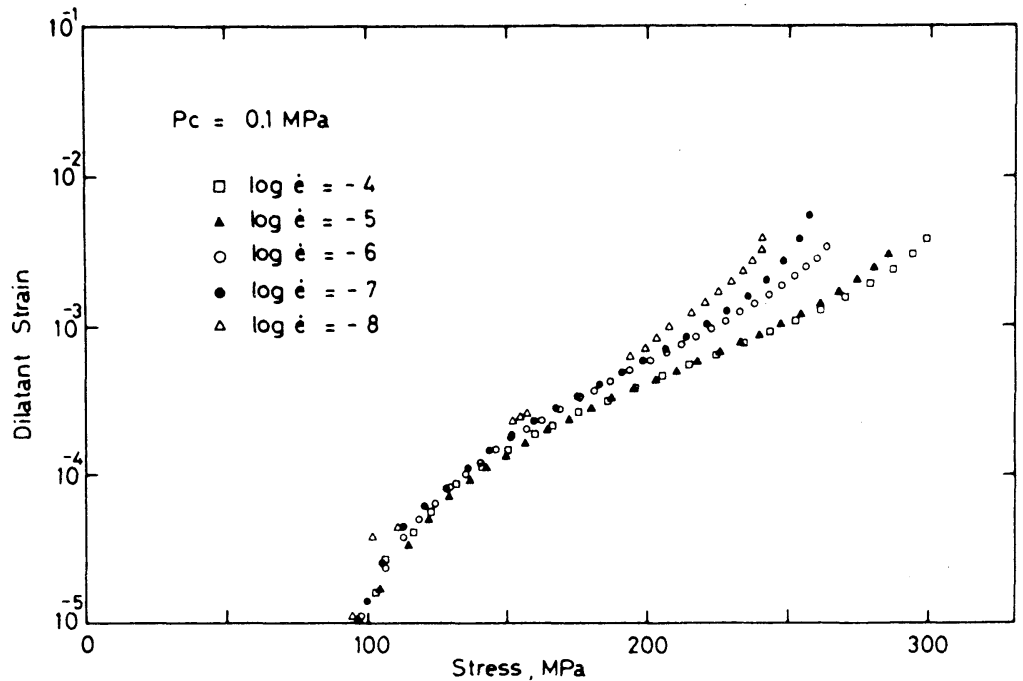

(b)

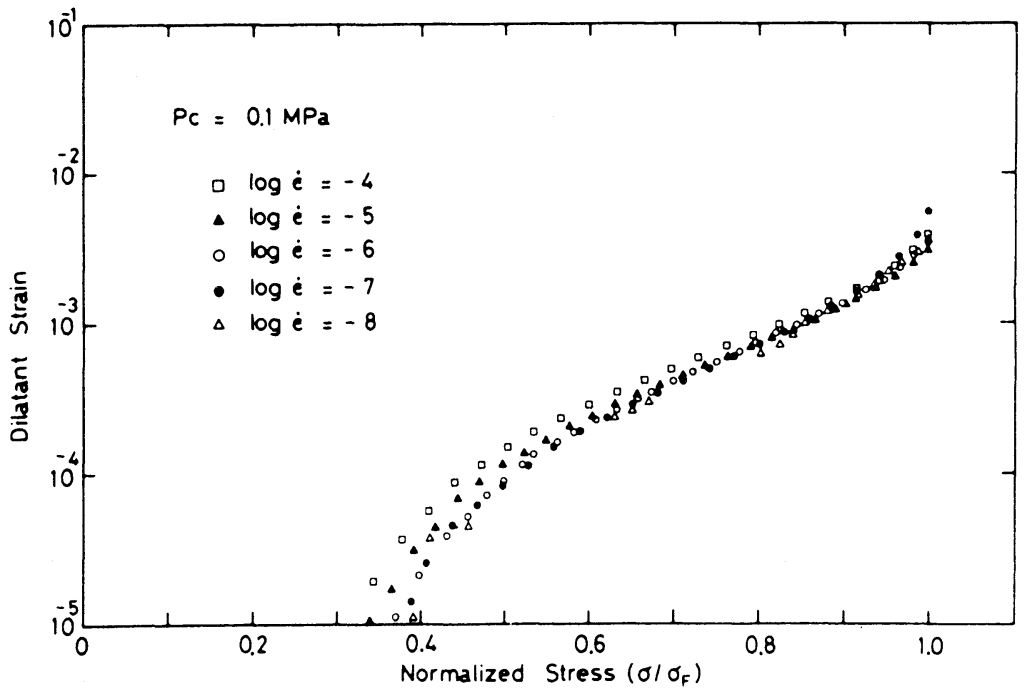

Fig. 6. Variation of dilatant strain (a) with stress and (b) with stress normalized by strength at various strain rate at a constant confining pressure of $0.1 \mathrm{MPa}$ [MAsud et al. (1987)]. 


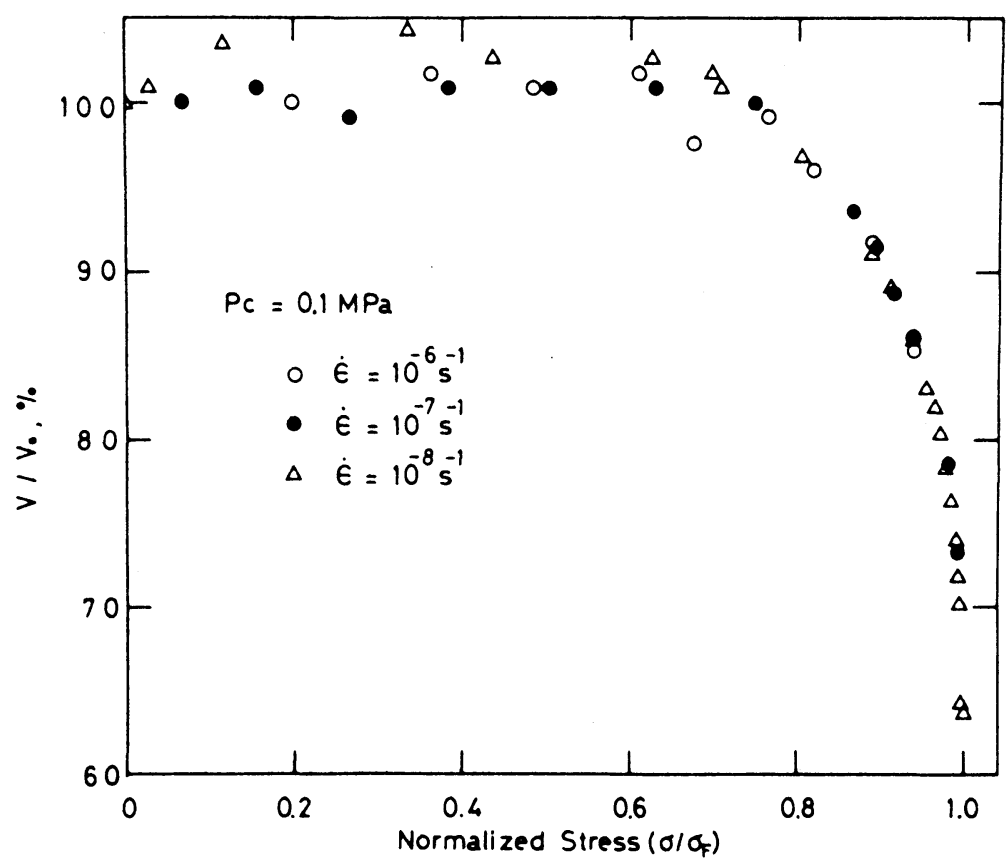

Fig. 7. Variation of P-wave velocities with applied stress normalized by strength at confining pressure of $0.1 \mathrm{MPa}$ [MASuda et al. (1987)].

示すように歪速度によってその変化曲線が変わってくる が，Fig. 6(a) の横軸を破壊強度で規格化した応力として プロットしなおすと，その変化曲線の形は一致する (Fig. 6(b)). P 波速度変化についても同様に破壊強度で 規格化した応力に対する変化曲線は一致する (Fig. 7). ダイラタンシーと P 波速度変化に関しては歪速度依存 性が破壊強度の歪速度依存性にくみこまれている。これ らのことは岩石の変形・破壊の際にみられる種種の性質 の歪速度依存性が, 共通した概念で説明できることを示 唆している.

これら時間に関するスケーリング則は，クラック先端 部での応力腐食過程 [MICHALSKE and FreIMAN (1982)] による Subcritical クラックのゆっくりした成長の概念 で説明されている [MizUTANi et al. (1982)]. Subcritical クラックの成長率 $V$ は

$$
V=A P_{\mathrm{H}_{2} \mathrm{O}}^{n} \exp \left(-\frac{U-f V_{I}^{*} \sigma}{R T}\right)
$$

で表わされる [WIEDERHORN (1974)].ここで $A$ と $n$ は定 数, $P_{\mathrm{H}_{2} \mathrm{O}}$ は $\mathrm{H}_{2} \mathrm{O}$ の水蒸気圧, $R$ はガス定数, $T$ は絶対温 度, $U$ は応力腐食過程の活性化エネルギー， $V_{\mathrm{I}}^{*}$ *は活性 化体積， $\sigma$ は加えられた応力，そして $f$ はクラック先端 部での応力値の $\sigma$ に対する比である. たとえば, 岩石の 破壊強度は, クラックの長さがある臨界値に達したと き，となりあうクラック同士が次々につながってマクロ

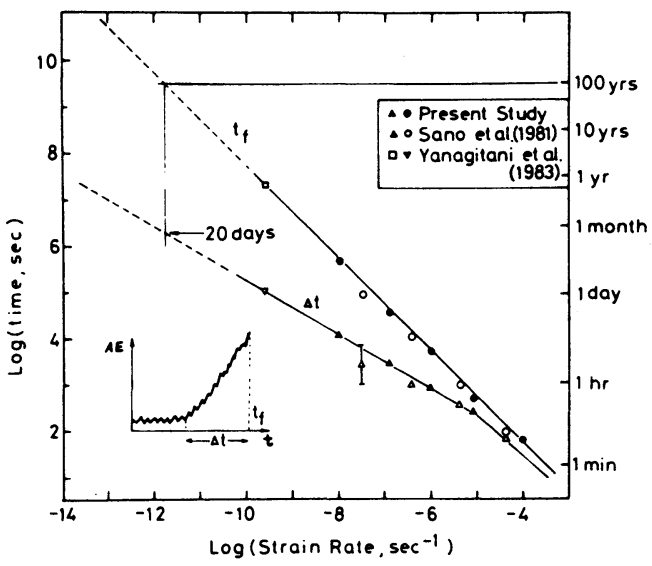

Fig. 8. Variation of times to failure, $t_{\mathrm{f}}$, and time intervals of $\mathrm{AE}$ active phase, $\Delta t$ with strainrate [MizUTANi et al. (1985)].

な破壊面を形成するときの応力值 $\sigma\left(\sigma_{\mathrm{F}}\right.$ とする）である と考えると, (2)式を時間で積分し

$$
\sigma_{\mathrm{F}}=\frac{2.30 R T}{f V_{I}^{*}}\left(\log \dot{\varepsilon}+B_{0}\right)
$$

( $B_{0}$ は定数, $\dot{\varepsilon}$ 歪速度) がえられ, 実験的に得られた式 (1)を説明できる.

岩石に一定歪速度で応力を加えていくと， ある時期か ら発生する $\mathrm{AE}$ が急増した後，破壊にいたる．この $\mathrm{AE}$ 
(a)

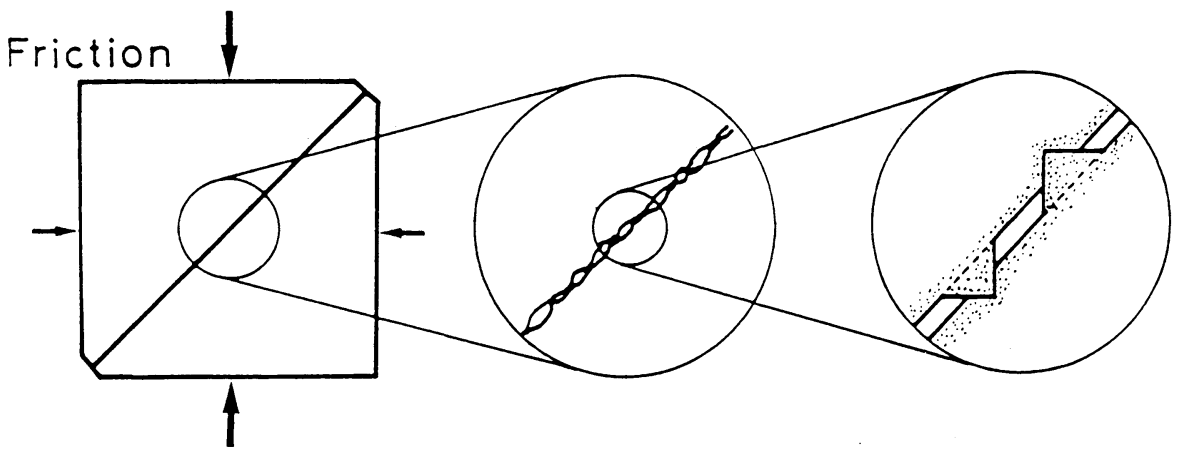

(b)

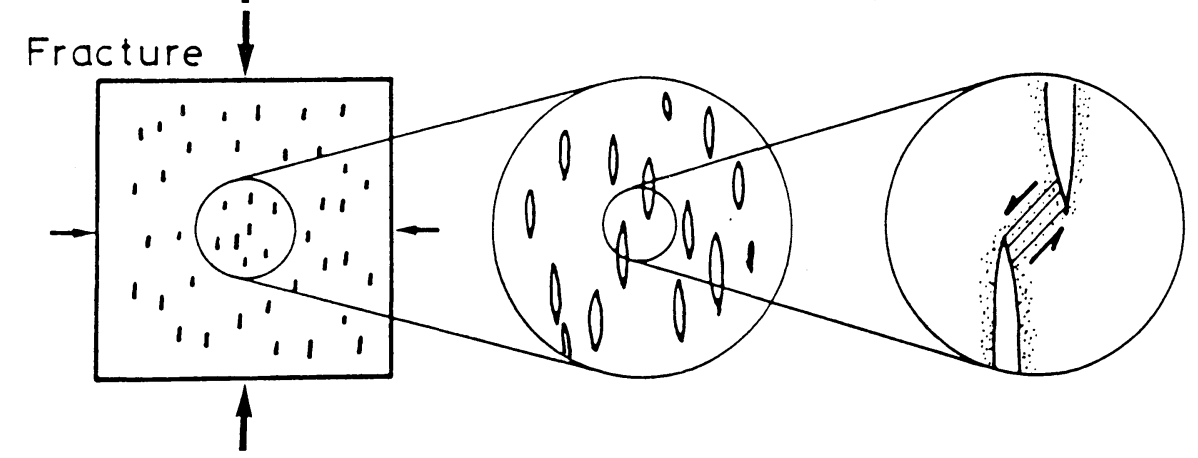

Fig. 9. Microscopic view of fracture process and slip process, showing the interrelationship between the fracture experiment and friction experiment [Mizutani (1987)].

が急増し始める時期は歪速度が小さくなるほど最終破壊 直前に近くなる [SANo etal. (1981), MASUda et al. (1987)]. 地震サイクルにおける地款応力変化を非常に単 純化して考え MizUTANi et al. (1985) は自然界の時間ス ケールまでこの結果を外挿して, Fig. 8 に示すように, 破壊までの時間間隔が約 100 年のとき $\mathrm{AE}$ が活発にな る時間は約 20 日間という結果をえた. 主破壊より約 20 日前から前震活動がみられるということである。これは 主破壊の間隔約 100 年と比べると非常に短い.すなおち 前震として観測される前兆現象の期間は非常に短いとい うことになる。

地震をシミュレートする方法として岩石の破壊実験の ほかに，既存の断層面にズリ応力をあたえてすべりをお こさせるすべり実験がおこなわれている，自然地震の多 くが既存の断層にそってのすべりであることから，地震 断層運動理解のためにすべり実験は有効な手段である. 岩石の摩擦力はすべり面の凹凸部の脆性破壊による抵抗 力によるものと考えられる.すずり面を微視的にみれば Fig. 9(a) 右端のようになっているであろう.これは $2 つ$ の面の凹凸部の破壊実験を行っているのに等しい，従っ て,すべり実験は微視的にみた凹凸部の 3 軸圧縮実験と 同等である．また， 3 軸圧縮実験においても最終破壊直 前では伸張クラック同士をつなぐようなせん断破壊が生 じており, 微視的にみれば Fig. 9(b) 右端に細い線で示
すようにクラック先端部をつなぐ部分にすべり実験を小 さくしたようなすべりが生じている，従って, 岩石破壊 実験とすべり実験はミクロな物理過程をみると互いに相 補的な役割をむっていて，2 種類の実験の総合的理解が 必要である [水谷 (1987)]. 岩石の摩擦特性やすべり実 験に関しては最近の莱原 (1989) のすぐれた総合報告が あり参考文献も最新のものが集められているので, 本論 ではすべり過程のスケーリングに関するもののみをとり あげる。

すべり過程の時間に関するスケーリング則として, DIETERICH (1978) は実験結果に基づき, 静摩擦力は固着 時間の対数に比例して増大し, 動摩擦力はすべり速度の 増加とともに減少するという次の式をえた.

$$
\begin{aligned}
& \mu_{\mathrm{s}}=\mu_{0}+A \log (B t+1) \\
& \mu_{\mathrm{d}}=\mu_{0}+A \log \left(B d_{\mathrm{c}} / V+1\right)
\end{aligned}
$$

ここで $\mu_{\mathrm{s}}, \mu_{\mathrm{d}}$ はそれぞれ静摩擦係数之動摩擦係数，Vは すべり速度, $d_{\mathrm{c}}$ は臨界変位量, $\mu_{0}, A, B$ は定数である. RUINA (1983) はすべり面の状態も変数, $\theta$, として導入 した次の式をあたえた。

$$
\begin{aligned}
& \mu=\mu_{0}+\theta+A \ln \left(V / V_{\mathrm{C}}\right) \\
& \dot{\theta}=\left(-V / d_{\mathrm{c}}\right)\left[\theta+B \ln \left(V / V_{\mathrm{C}}\right)\right]
\end{aligned}
$$

$V$ はすべり速度, $\mu_{0}, A, B, V_{\mathrm{C}}$ は定数である. 花こう岩に おいては $A<B$ となる. 定常状態 $(\dot{\theta}=0)$ ではすべり速度 が大きいほど摩擦力は小さくなる.このようにすべり過 


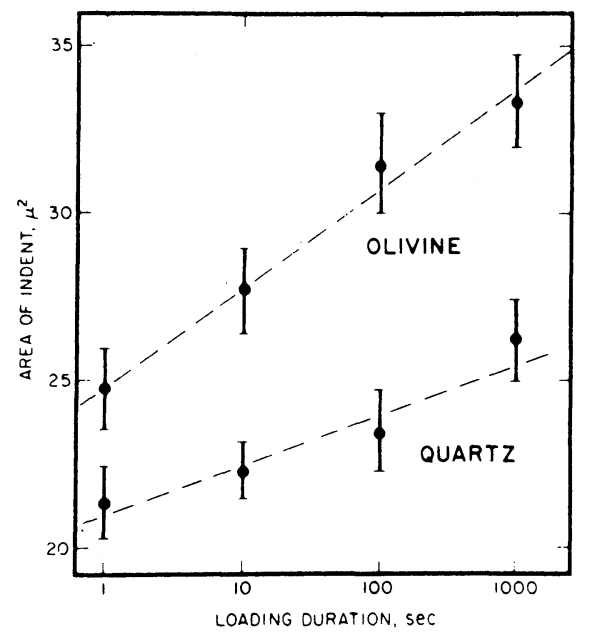

Fig. 10. Real contact area versus loading time for quartz and olivine measured in microindentation experiments. Each data point is an average for about 25 individual measurements [SCHOLZ and ENGELdER (1976)].

程にす時間的变化に依存する性質がある。これらすべり 過程の時間スケーリングあすべり面の凹凸部の破壊を考 慮して解釈することができる．すなわち接触面のそれぞ れが凹凸をもち, それらが真に接触している部分, アス ペリティー，の面積を $A r$ とする．これらの面積で面に かかっている垂直荷重 $N$ をちょうど支えている，すな わち垂直荷重を支えるため接触点がつぶれて最終的に面 積 $A r$ でつりあっている，とすると

$$
N=p A r
$$

という関係で表わされる。ここで $p$ は面を作る物質の強 度の尺度である penetration hardness である，接触部 分には非常に大きな圧縮応力がかかり固着が㧍こる.す ベりをおこすためにはつながった部分にずり破壊をおこ さなければならないので, 摩擦力 $F$ は接触点のずり強度 $s$ の和となる。すすなち

$$
F=s A r
$$

摩擦係数は $F$ と $N$ の比で

$$
\mu \equiv F / N=s / p
$$

で表わされる. ScHOLZ and ENGELDER (1976) の実験 データによれば，Fig. 10 に示すように

$$
A r=A r_{0}+B \log (t)
$$

という関係がある.ここで, $t$ は接触時間, $A r_{0}$ と $B$ は定 数である. (11) 式を(8) 式に代入し， $N$ を定数と考え $p$ を消去すれば (10) 式より

$$
\mu=\frac{s A r_{0}}{N}+\frac{s B}{N} \log t
$$

がえられ，摩擦係数の時間依存性の経験式を説明するこ

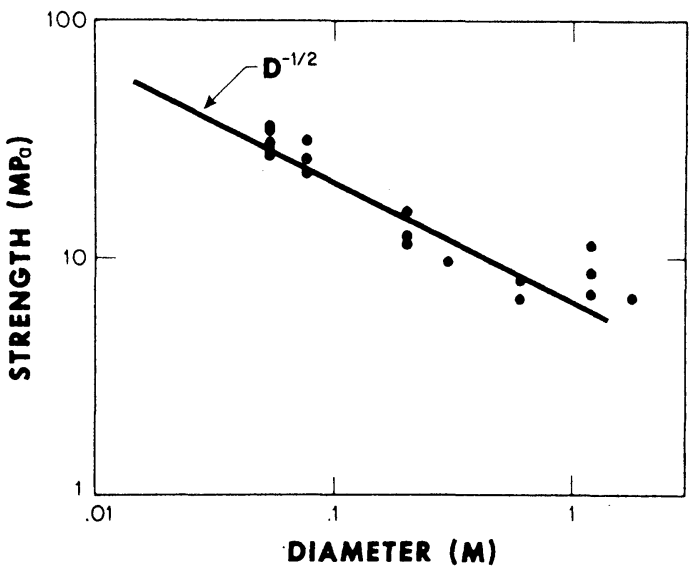

Fig. 11. The relationship between specimen size and strength [Scholz (1990)]. The data are for quartz diolite from PRATT et al. (1972)

とができる [SCHOLZ (1990)]. このようにすべり過程の 時間スケーリングは破壊の時間スケーリングと密接に関 係している.

岩石の摩擦現象には，急激なすべりが不連続におこる 固着一すべり（スティック・スリップ）という現象があ る. 浅発地震は断層面での固着一すべり現象であると考 えることもできる．この固着一すべりにおける急激なす べりという不安定性は, 摩擦力がすべり速度の増加にと あなって減少するということによって生じているあのと 考えられる. 実際, Shimamoto (1986) は八ライト (halite) を使ったすべり実験で, 固着一すべりは摩擦係数 がすべり速度の増加に対して減少する条件でのみおきて いることを示している.

\section{§4. 破壊のスケーリング則（その 2） 空間に関す るスケーリング}

空間（サイズ）に関するスケーリング則については, まだよく知られているとはいえない，実験的な面からい えば，時間に関するスケーリングを調べるために歪速度 については 4 ケ夕程度の範囲で実験できるのに対して, サイズについては, せいぜい 2 ケ夕程度の範囲でしか実 験できない，従って，破壊過程の空間（サイズ）依存性 に関するデータを得にくいという事情がある.

破壊強度のサイズ依存性に関しては, 大きな寸法の岩 石の破壊強度は小さな寸法の岩石の破壊強度より小さく なる [BRACE (1981), PRATT et al. (1972)]. 経験的には圧 縮強度 $\sigma_{\mathrm{C}}$ は特長的なサイズ $d$ に伴って

$$
\sigma_{\mathrm{C}}=m d^{-\zeta}
$$

で表わされる式で減少することが知られている.ここで 
$\zeta$ は 1 より小さい定数, $m$ は規格化ファクターである.

Fig. 11 は $0.05 \mathrm{~m}<d<1.0 \mathrm{~m}$ の範用で $\zeta=1 / 2$ として (13) 式をフィットさせた例である [ScHOLZ (1990)よ り．この関係はクラックなどの試料内欠陥サイズのサ ンプルサイズ依存性によるあのと解釈される. クラック の発生成長や岩石の強度は最も大きな先在クラックに よってコントロールされていて, クラック先端近傍の応 力と変位を表わす係数である応力拡大係数， $K$, を使っ て脆性破壊発生の条件が $K \geqq K c$ で与えられると考元 る. あし岩石の強度が破壊靵性 $K c$ で与えられ，最長ク ラックの平均の長さが $d$ に比例して長くなるとすると, 一般的に応力拡大係数, $K$, が

$$
\begin{aligned}
& K=\sigma(\pi C)^{1 / 2} \\
& (\sigma ; \text { 応力, } C \text { クラックを代表する寸法 })
\end{aligned}
$$

という形で表わされることを考えれば，強度のサイズ依 存性を表わす経験式 (13) が説明できる [SCHOLZ (1990)].

すべり現象の寸法効果を解明するため DIETERICH (1981) は長さ $2 \mathrm{~m}$ の断層面をむった大型試料を用いて 摩擦実験をおこなった。彼は，断層全体がすべらない場 合であ不安定すべりが発生することを示した。

葉原・他 (1987) らのグループは長さ $40 \mathrm{~cm}$ の既存断 層をむつ岩石を用いてすべり実験をおこない，その結果 は彼らの一連の論文に詳しくまとめられている [來原 (1989), OHNAKA et al. (1987)など]. 彼らは，異なる粗 さの人工断層面形状のパワースペクトルには異なるコー ナー波長 $\lambda_{\mathrm{C}}$ が存在し，コーナー波長よりも短波長域で はパワースペクトルは波長のべき乗に比例することを示 した．不安定すべりの伝播過程を記述するのに用いられ る slip-weakening モデルによると，破壊先端域での応 力がある值に達すると破壊が始まりすべり量の増加とと あに断層面上の応力が解放される．このときすべり量が 臨界值 $d_{\mathrm{c}}$ をこえて以後応力は一定となる．固着-すべり の際に，この臨界変位量 $d_{\mathrm{c}}$ は $\lambda_{\mathrm{c}}$ と比例関係にある。 さ らに不安定すべりは断層のすべり量 $2 D$ が $\lambda_{\mathrm{c}}$ よりあ大 きくなる条件で発生する (Fig. 12)，室内実験の結果を外 挿するとマグニチュード 6 程度の地震をひきおこす断 層の場合, コーナー波長 $\lambda_{\mathrm{c}}$ は約 $1 \mathrm{~m}$ となる.

OHNAKA et al. (1987) は破壊域先端でのいくつかの破 壊力学パラメータのあいだの関係を調べた，彼らは，破 壊の物理量で，寸法に依存する量と依存しない量をみき わめた．彼らによると破損領域の大きさ, 臨界変位量, 最大すべり加速度は寸法に依存する量であり, 応力降下 量, 破壊伝播速度, すべり速度は寸法に依存しない量で ある.このように破壊やすべり現象において寸法に依存 する物理量と依存しない物理量を確かめ, 寸法に依存す

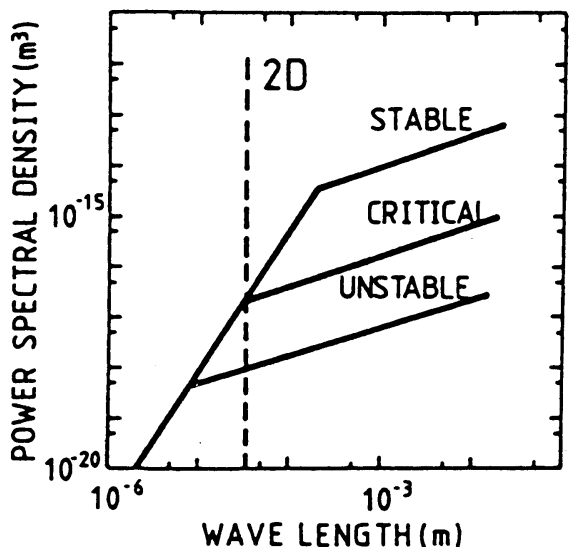

Fig. 12. Idealized spectral curves of the surface profile. Each curve has spectral corner $\lambda_{\mathrm{C}}$. Stick-slip instability occurs when $2 \mathrm{D}$ (twice the relative displacement) $>\lambda_{\mathrm{C}}$ [KUwAHARA et al. (1987)].

るものはそのスケーリング法則を明らかにしていくとい う方法が，今後破壊の空間スケーリングを明らかにして いくうえで有効であろう.

破壊に関するサイズ効果に関しては, 岩石の構造の不 均質性やその波長の違いを，すべりに関しては現象論で はなく摩擦の微視的なプロセスに迫った法則性を明らか にしていく必要がある.

\section{§5. 今後の課題}

室内実験に打ける破壊やすべり現象を地震に対応させ て考えるためには，時間的・空間的スケールに関するス ケーリング則を確立することが一番重要である。また, 実際に地震が扔こる自然界の状態での, 温度の効果, 水 の存在などの環境の効果についてはほとんどわかってい ない，たとえば摩擦の速度依存性に関する温度の影響の ように相矛盾するような実験結果が得られている場合も ある [莱原 (1989)]．実際に地震のおこる地款内部ある いは上部マントル部では, 地下深くにいくに従って大き な圧力, 封圧がかかっている. 岩石は高封圧下では低封 圧下とは異なった破壊様式を示すことも報告されている [例えば SHIMADA and CHо (1990)]. 今後, 地震の場で の環境がスケーリング則に与える影響む明らかにしてい かなければならない重要課題である.

\section{謝辞}

本論文をまとめるにあたり，深尾良夫氏，佐野 修氏， 飯尾能久氏, 西澤 修氏, 楠瀬勤一郎氏, 葉原保人氏, 長秋雄氏には貴重なコメントをいただいた。記して感謝 の意を表します。 


\section{文献}

Brace, W. F., 1981, The effect of size on mechanical properties of rock, Geophys. Res. Lett., 8, 651-652.

Brace, W. F. and J. D. Byerlee, 1966, Stick-slip as a mechanism for earthquakes, Science, 153, 990-992.

Boler, F. M., 1990, Measurements of radiated elastic wave energy from dynamic tensile cracks, J. Geophys. Res., 95, 2593-2607.

Boler, F. M. and H. Spetzler, 1986, Radiated seismic energy and strain energy release in laboratory dynamic tensile fracture, Pure Appl. Geophys., 124, 759-772.

Boler, F. M., H. A. Spetzler and I. C. Getting, 1984, Capacitance transducer with a point-like probe for receiving acoustic emissions, Rev. Sci. Instrum., 55, 1293-1297.

Dieterich, J. H., 1978, Time-dependent friction and the mechanics of stick slip, Pure Appl. Geophys., 116, 790-806.

Dieterich, J. H., 1981, Potential for geophysical experiments in large scale tests, Geophys. Res. Lett., 8, 653-656.

平田隆幸・柳谷 俊・寺田 孚, 1985 , 大島花こう岩に おけるクリープ時の $\mathrm{AE}$ 発生時系列について, 地震 2 , 38, 159-172.

Hirata, T., 1987, Omori's power law aftershock sequences of microfracturing in rock fracture experiment, J. Geophys. Res., 92, 6215-622.

Hirata, T., T. SAtoh and K. Ito, 1987, Fractal structure of spatial distribution of microfracturing in rock, Geophys. J. Roy. Astr. Soc., 90, 369-374.

KAGAN, Y. Y. and L. KNOPOFF, 1980, Spatial distribution of earthquakes: the two-point correlation function, Geophys. J. Roy. Astr. Soc., 62, 303-320.

Kusunose, K. and O. Nishizawa, 1986, AE gap prior to local fracture of rock under uniaxial compression, J. Phys. Earth, 34, S45-S56.

楠瀬勤一郎・西澤 修・伊藤久男 - 石戸経士 ・長谷川 功, 1981 , 岩石の一軸圧縮試験における $\mathrm{AE}$ 発震機 構, 地震 2, 34, 241-250.

楠瀬勤一郎, 西澤 修, 小内 薫, 1982 , 一軸圧縮下の 岩石中に観測された AE 空白域, 地震 2,39, 289-300.

葉原保人, 1989 , 岩石の摩擦特性之地震断層運動論, 地 震 2, 42, 105-116.

葉原保人, 大中康譽, 山本清彦, 平沢朋朗, 1987, 断層 面の形状と断層運動, 数理地震学 (II), 斉藤正徳編, 36-48.

Lockner, D. and J. D. Byerlee, 1977, Hydrofracture in Weber sandstone at high confining pressure and differential stress, J. Geophys. Res., 82, 2018-2026.

Main, I. G., P. G. Meredith and C. Jones, 1989, A reinterpretation of the precursory seismic $b$-value anomaly from fracture mechanics, Geophys. J., 96, 131-138.

Masuda, K., H. Mizutani and I. Yamada, 1987, Exper- imental study of strain-rate dependence and pressure dependence of failure properties of granite, J. Phys. Earth, 35, 37-66.

Masuda, K., H. Mizutani, I. Yamada and Y. Imanishi, 1988, Effects of water on time-dependent behavior of granite, J. Phys. Earth, 36, 291-313.

Michalske, T. A. and S. W. Freiman, 1982, A molecular interpretation of stress corrosion in silica, Nature, 295, 511-512.

水谷 仁, 1987, 岩石破壊実験の基本問題, 地震予知研 究シンポジウム, 229-236.

Mizutani, H., I. Yamada and K. Masuda, 1985, Timedependent properties of rocks and its implications on earthquake prediction, Earthq. Predict. Res., 3, 595-605.

Mizutani, H., H. Spetzler and H. Murakami, 1982, Brittle behavior of rocks at high pressure, in HighPressure Research in Geophysics, ed. Akimoto and Manghnani, 207-215, Center for Academic Publications Japan, Tokyo.

Mogi, K., 1962a, Study of elastic shocks caused by the fracture of heterogeneous materials and its relations to earthquake phenomena, Bull. Earthq. Res. Inst., 40, 125-173.

MogI, K., 1962b, Magnitude-frequency relation for elastic shocks accompanying fractures of various materials and some related problems in earthquakes, Bull. Earthq. Res. Inst., 40, 831-853.

Mogr, K., 1967, Earthquakes and fractures, Tectonophysics, 5, 35-55.

MogI, K., 1968, Source locations of elastic shocks in the fracturing process in rocks (1), Bull. Earthq. Res. Inst., 46, 615-658.

Mogi, K., 1973, Rock fracture, Ann. Rev. Earth Planet. Sci., 1, 63-84.

茂木清夫, 1978, 岩石力学々地震, 岩波講座 地球科学 8, (金森博雄編), 211-262.

MogI, K., 1979, Two kinds of seismic gaps, Pure Appl. Geophys., 117, 1172-1186.

西澤 修・楠瀬勤一郎・小内 董, 1981 , 一軸圧縮応力 下で発生するアコースティック・エミッション震源の 時間一空間分布，地質調查所月報，32,473-486.

Nishizawa, O., K. Onai and K. Kusunose, 1985, Hypocenter distribution and focal mechanism of $\mathrm{AE}$ events during two stage creep in Yugawara andesite, Pure Appl. Geophys., 122, 36-52.

大中康譽, 1987, 地震の発生機構, 地震の事典 (宇津徳 治総編集), 朝倉書店, 194-216.

OHNAKA, M. and K. Mogr, 1982, Frequency characteristics of acoustic emission in rocks under uniaxial compression and its relation to the fracturing process to failure, J. Geophys. Res., 87, 3873-3884.

Ohnaka, M., Y. Kuwahara and K. Yamamoto, 1987, Constitutive relations between dynamic physical parameters near a tip of the propagating slip zone during stick-slip shear failure, Tectonophysics, 144, 109-125. 
Paterson, M. S., 1978, Experimental rock deformation-The brittle field, Springer-Verlag, Berlin, 254 pp.

Pratt, H. R., A. D. Black, W.S. Brown and W.F. BRACE, 1972, The effect of specimen size on the mechanical properties of unjointed diorite, Int. J. Rock Mech. Min. Sci., 9, 513-529.

RuinA, A., 1983, Slip instability and state variable friction law, J. Geophys. Res., 88, 10359-10370.

Sano, O., I. Ito and M. Terada, 1981, Influence of strain rate on dilatancy and strength of Ohshima granite under uniaxial compression, J. Geophys. Res., 86, 9299-9311.

佐藤隆司・出原 理 - 西澤 修 - 楠瀬勤一郎, 1986, 三 軸応力下で発生する AE の震源分布と発震機構一安山 岩中で発生する $\mathrm{AE}$ の発震機構一, 地震 $2,39,351-$ 360.

佐藤隆司・楠瀬勤一郎・西澤 修, 1987, ミニコン ピューターを用いた AE 波形計測処理システム一高速 ディジタル記録と自動震源決定一，地質調查所月報, 38, 295-303.

Scholz, C. H., 1968a, The frequency-magnitude relation of microfracturing in rock and its relation to earthquakes, Bull. Seism. Soc. Am., 58, 399-415.

Scholz, C. H., 1968b, Experimental study of the fracturing process in brittle rock, J. Geophys. Res., 73, 1447-1454.

Scholz, C. H., 1990, The mechanics of earthquakes and faulting, Cambridge Univ. Press., 439 pp.
Scholz, C. H. and J. T. Engelder, 1976, The role of asperity indentation and ploughing in rock friction I . Asperity creep and stick-slip, Int. J. Rock Mech. Min. Sci. \& Geomech. Abstr. 13, 149-154.

Shimada, M. and A.Cho, 1990, Two type of brittle fracture of silicate rocks under confining pressure and their implications in the earth's crust, Tectonophysics, 175, 221-235.

Shimamoто, T., 1986, Transition between frictional slip and ductile flow for halite shear zones at room temperature, Science, 231, 711-714.

Sondergeld, C. H. and L.H. Estey, 1982, Source mechanisms and microfracturing during uniaxial cycling of rock, Pure Appl. Geophys., 120, 151-166.

Spetzler, H., N. Soga., H. Mizutani and R. J. Martin, III, 1977, Strain fields associated with fracture under high pressure, viewed with holographic interferometry, in High Pressure Research: Applications in Geophysics,ed. Manghnani and Akimoto, 625-635, Academic Press, New York.

Wiederhorn, S. M., 1974, Subcritical crack growth in ceramics, in Fracture Mechanics of Ceramics, Vol. 2, Microstructure, Materials, and Applications, ed. R. C. Bradt, D. P. H. Hasselman, and F. F. Lange, pp. 613-646, Plenum Press, New York.

Yanagidani, T., S. Ehara, O. Nishizawa, K. Kusunose and M. TERADA, 1985, Localization of dilatancy in Ohshima granite under constant uniaxial stress, J. Geophys. Res., 90, 6840-6858. 